\title{
Analisis Perilaku Etika Lingkungan Hidup Siswa SMAN di Jember
}

\author{
Fitri Amaliyah $^{1,{ }^{*}}$, Sudarti Sudarti ${ }^{1)}$, Wachju Subchan ${ }^{1)}$ \\ ${ }^{1)}$ Universitas Jember \\ *fitri110298@gmail.com
}

\begin{abstract}
Abstrak: Etika lingkungan merupakan salah satu faktor yang menentukan terciptanya lingkungan yang bersih dan sehat, serta salah satu komponen yang ada dalam pelaksanaan Education for Sustainable Development (ESD). Dunia sedang menggalakkan pelaksanaan ESD, yaitu pendidikan untuk pembangunan berkelanjutan yang memungkinkan setiap manusia untuk mendapatkan dan memiliki perilaku untuk membentuk masa depan berkelanjutan bagi generasi berikutnya. Penelitian ini bertujuan menganalisis perilaku etika lingkungan siswa SMAN di Jember. Metode penelitian yang digunakan adalah penelitian survei menggunakan sembilan prinsip etika lingkungan. Variabel yang diukur meliputi sikap hormat terhadap alam, sikap tanggung jawab, solidaritas kosmis, kasih sayang dan kepedulian terhadap alam, tidak merugikan, hidup sederhana dan selaras dengan alam, keadilan, demokrasi, dan integritas moral. Pengumpulan data dilakukan melalui kuisioner dalam bentuk googleform. Analisis data penelitian menggunakan analisis deskriptif. Hasil penelitian menunjukan nilai rata - rata perilaku etika lingkungan siswa SMAN di Jember sebesar 74,38 dengan kategori sedang. Prinsip yang memiliki persentase terendah adalah prinsip tidak merugikan, yaitu sebesar $52 \%$. Prinsip yang memiliki persentase tertinggi adalah prinsip demokrasi, yaitu 98\%.
\end{abstract}

Kata Kunci: Etika Lingkungan, Analisis Perilaku, Siswa SMAN, Jember.

\section{PENDAHULUAN}

Manusia adalah penyebab utama dari kerusakan dan pencemaran lingkungan hidup (Keraf, 2010). Kerusakan dan pencemaran lingkungan hidup akan menjadi krisis bagi kehidupan manusia. Krisis lingkungan hidup hanya bisa diatasi dengan melakukan perubahan cara pandang dan perilaku manusia terhadap alam secara fundamental (Næss et al., 2016). Cara pandang dan perilaku manusia terhadap alam diwujudkan dalam etika lingkungan. Etika merupakan perilaku manusia dilihat dari baik buruknya dengan ajaran yang berhubungan dengan perintah dan larangan (Ratih et al., 2020). Etika lingkungan adalah perilaku manusia dalam dimensi norm, attitude, etiquette, dan morality kepada lingkungan yang mencakup komponen biotik dan abiotik. Di samping itu, etika Lingkungan tidak hanya berbicara mengenai perilaku manusia terhadap alam, namun juga mengenai relasi di antara semua kehidupan alam semesta, yaitu antara manusia dengan manusia yang mempunyai dampak pada alam dan antara manusia dengan makhluk hidup lain atau dengan alam secara keseluruhan (Said \& Nurhayati, 2020). Berbagai prinsip moral lingkungan yang merupakan petunjuk atau arah perilaku praktis manusia dalam mengusahakan terwujudnya moral lingkungan diatur dalam etika lingkungan (Hudha et al., 2019).

Etika lingkungan menjadi faktor penting dalam menciptakan lingkungan yang bersih dan sehat, serta menjadi komponen pelaksanaan ESD (Education for Sustainable Development). ESD memberdayakan siswa semua jenjang dengan pengetahuan, keterampilan, nilai and perilaku untuk menemukan hubungan tantangan global yang sedang dihadapi, seperti perubahan iklim, degradasi lingkungan, kepunahan hayati, kemiskinan dan ketidaksetaraan. Dalam perspektif aksiologi, manfaat dari pengaplikasian etika lingkungan dalam pendidikan yang diharapkan muncul adalah terbangunnya pengetahuan konseptual peserta didik tentang etika lingkungan, terbangunnya pengetahuan prosedural untuk mengembangkan keterampilan dan kapasitas peserta didik dalam menerapkan prinsip-prinsip etika lingkungan dan tiga pilar pembengaunan berkelanjutan (Faizah, 2020). Salah satu aspek yang dapat menjadi penentu etika lingkungan adalah perilaku. Perilaku merupakan tindakan atau aktivitas dari manusia itu sendiri yang mempunyai bentangan yang sangat luas (Nissa \& Christiawan, 2018). Perilaku siswa dalam menghadapi krisis lingkungan di sekitarnya mencerminkan etika lingkungan yang dimiliki. 
Upaya untuk mengatasi kekurangan dalam pendidikan lingkungan hidup yakni sekolah seharusnya memberikan pengajaran praktik yang efisien dan efektif dalam rangka meningkatkan prilaku peduli terhadap lingkungan dan juga lingkungan belajar seharusnya mengajak siswa belajar di alam terbuka untuk mengamati, mempraktekkan dan menguji problem permasalahan lingkunan (Akbar \& Ali, 2021).

Salah satu bentuk observasi awal perilaku etika lingkungan hidup siswa, maka dilakukan penelitian yang bertujuan menganalisis perilaku etika lingkungan siswa SMAN di Jember. Pengukuran perilaku etika lingkungan dilakukan menggunakan sembilan prinsip etika lingkungan. Prinsip etika lingkungan adalah sikap hormat terhadap alam, sikap tanggung jawab, solidaritas kosmis, kasih sayang dan kepedulian pada alam, tidak merugikan, hidup sederhana dan selaras dengan alam, keadilan, demokrasi, dan integritas moral (Keraf, 2010). Prinsip - prinsip etika lingkungan digunakan sebagai indikator untuk membuat kuisioner, sehingga kuisioner memiliki sembilan indikator. Setiap indikator dituangkan dalam bentuk penyataan perilaku, dengan tida pilihan jawaban, yaitu sering, jarang, dan tidak pernah.

\section{METODE}

Penelitian ini menggunakan random sampling method namun membatasi wilayah populasi, yaitu Kabupaten Jember. Random sampling method telah umum digunakan sejak abad 20 (Martino et al., 2018). Populasi penelitian ini adalah siswa SMAN di Jember, dengan jumlah tiga sekolah, yaitu SMAN 2 Jember, SMAN 4 Jember, dan SMAN 5 Jember. Sampel penelitian ini adalah 235 siswa SMAN di Jember. Setiap siswa akan mengisi kuisioner dalam bentuk googleform. Jenis data penelitian yang digunakan adalah data primer kuantitatif, berupa jawaban kuisioner siswa. Diagram alir (flowchart) adalah ilustrasi siklus aktivitas dimulai dari permulaan hingga akhir menggunakan simbol yang merepresentasikan langkahnya dan garis alurnya (Nita \& Kartikawati, 2020). Diagram alir berisika alur penelitian yang ditampilkan pada gambar 1 .

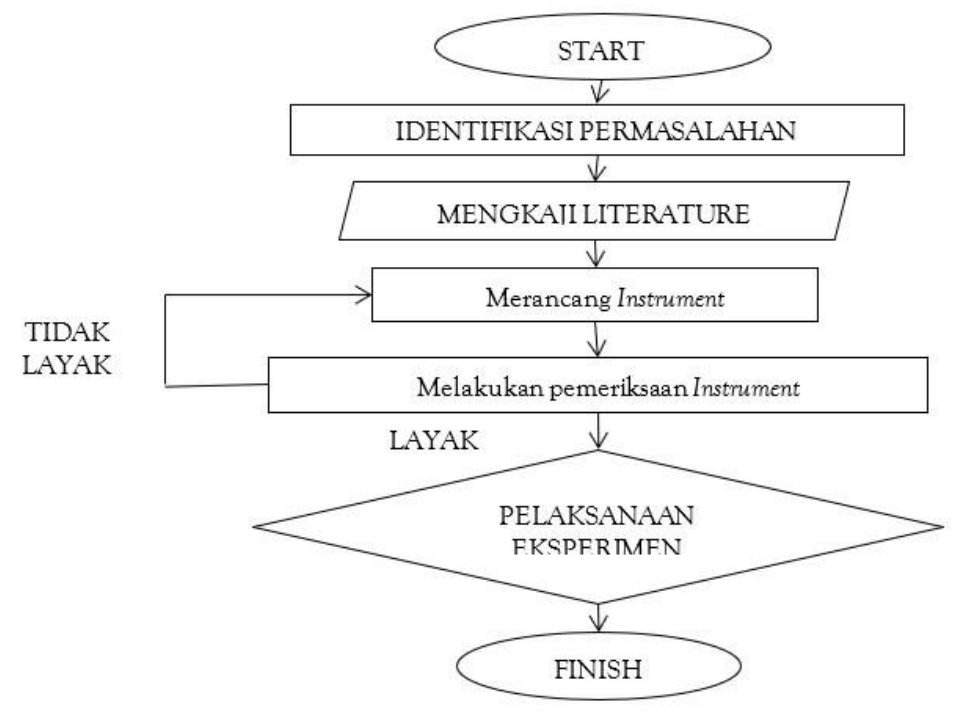

Gambar 1. Diagram Alur Penelitian (dokumen pribadi)

Analisis data dilakukan secara kuantitatis menggunakan persamaan (1), (2), (3), (4), dan (5) kemudian dibahas secara deskriptif.

$$
\begin{aligned}
& R=\frac{N_{\text {maks }}-N_{\text {min }}}{k} \\
& N=\frac{s}{0,48} \\
& \bar{N}=\frac{\sum_{i=1}^{n} N}{n} \\
& P=\frac{\sum_{i=1}^{n} s_{p}}{n \times 3} \times 100 \% \\
& R_{p}=1+3,322 \log (9)
\end{aligned}
$$


Keterangan:

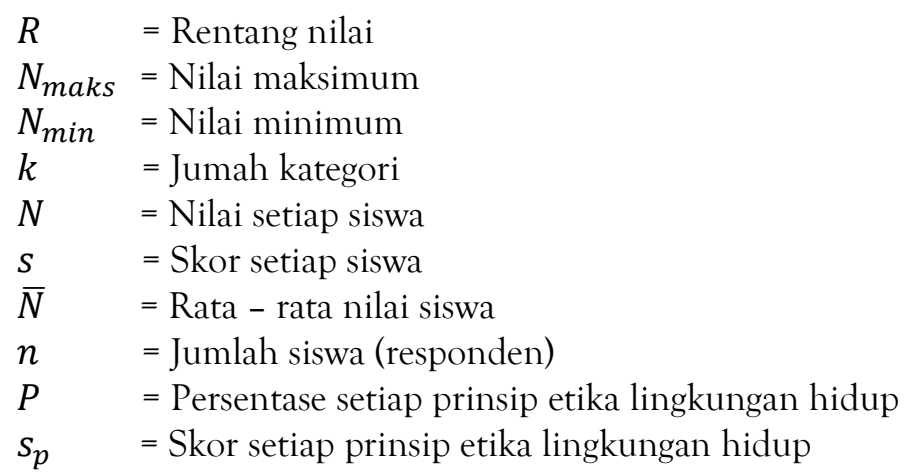

Pemberian skor memiliki rentang skor 1 sampai 3, sehingga skor yang akan didapatkan siswa antara 16 sampai 48. Persamaan (2) digunakan untuk menghitung nilai perilaku lingkungan hidup setiap siswa. Nilai minimal didapatkan saat skor siswa juga minimal, yaitu 16, dengan menggunakan persamaan (2), diketahui nilai minimum yang akan didapatkan siswa adalah 33,34 dan nilai maksimumnya adalah 100. Nilai minimum dan maksimum digunakan untuk menentukan rentang nilai dan kategorinya. Kategori penilaian psikomotorik adalah tinggi, sedang, dan rendah (Arikunto, 2013). Rentang nilai untuk kategori penilaian dihitung menggunakan persamaan (1). Persamaan (3) digunakan untuk menghitung rata - rata nilai perilaku lingkungan hidup siswa. Nilai rata - rata etika lingkungan siswa yang telah dihitung menggunakan persamaan (2) dikategorikan sesuai dengan tabel 1.

Tabel 1. Kategori rentang nilai

\begin{tabular}{cc}
\hline Rentang Nilai & Kategori \\
\hline $77,82-100$ & Tinggi \\
$55,58-77,81$ & Sedang \\
$33,34-55,57$ & Rendah \\
\hline
\end{tabular}

Persamaan digunakan untuk menghitung persentase setiap prinsip etika lingkungan hidup. Hasil persentase yang telah dihitung menggunakan persamaan (4) digambarkan menggunakan diagram batang, dimana setiap batang akan mewakilkan setiap kategori etika lingkungan hidup. Rentang untuk kategori persentase dihitung menggunakan persamaan (5), yaitu the formula for freight rates (Hayashi, 2020).

\section{HASIL DAN PEMBAHASAN}

Kuisioner telah dijawab oleh 235 siswa SMAN di Jember. SMAN yang berpatisipasi dalam penelitian ini adalah SMAN 2 Jember, SMAN 4 Jember, dan SMAN 5 Jember. Kuisioner diberikan kepada semua jenjang kelas di SMAN, yaitu kelas X, XI, dan XII. Data responden penelitian ditampilkan pada tabel 2.

Tabel 2. Daftar responden

\begin{tabular}{ccc}
\hline Sekolah & Kelas & Jumlah Partisipan (Siswa) \\
\hline \multirow{3}{*}{ SMAN 2 Jember } & X & 18 \\
& XI & 32 \\
& XII & 5 \\
\hline \multirow{2}{*}{ SMAN 4 Jember } & X & 58 \\
& XI & 12 \\
& XII & 97 \\
\hline \multirow{2}{*}{ SMAN 5 Jember } & X & 0 \\
& XI & 2 \\
\hline Jumlah Partisipan & & 11 \\
\hline
\end{tabular}

Persentase prinsip etika lingkungan seluruh responden digambarkan pada gambar 2. Prinsip yang memiliki persentase terendah adalah prinsip tidak merugikan, yaitu sebesar $52 \%$. Prinsip yang memiliki persentase tertinggi adalah prinsip demokrasi, yaitu 98\%. Semua prinsip memiliki persentase di atas 50\%. 
Prinsip yang memiliki persentase dibawah $75 \%$ adalah prinsip sikap hormat terhadap alam, solidaritas kosmis, dan tidak merugikan. Prinsip yang memiliki persentase diatas $75 \%$ adalah prinsip sikap tanggung jawab, kasih saying dan kepedulian pada alam, hidup sederhana dan selaras dengan alam, keadilan, demokrasi, dan integritas moral.

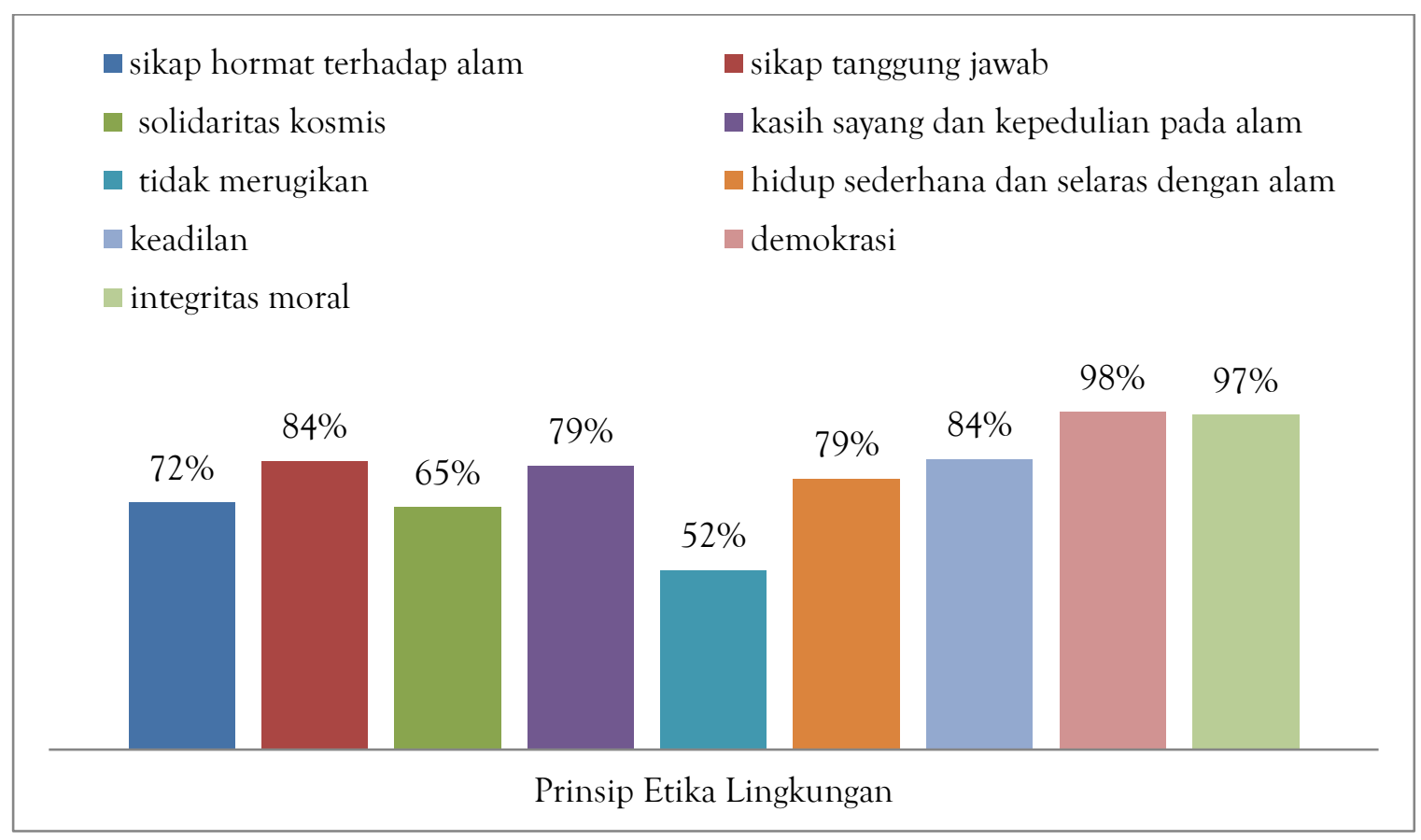

Gambar 2. Grafik Presentasi Prinsip Etika Lingkungan

Nilai perilaku etika lingkungan siswa dihitung menggunakan persamaan (2), kemudian dihitung rata rata nilai etika lingkungan hidup siswa menggunakan persamaan (3) dan didapatkan nilai sebesar 74,38 dengan kategori sedang. Psikomotorik siswa SMA berada pada tahap pertumbuhan, sehingga terdapat potensi untuk berkembang dan meningkat. Penilaian psikomotorik dengan katagori penilaian bertanya, menjawab, bekerjasama, memberi pendapat, penguatan kondisi minat dengan nilai persentase $71 \%$ sebagai katagori aktif (Andrasmoro et al., 2020). Aspek - aspek psikomotorik tersebut dipengaruhi oleh faktor internal dan eksternal. Faktor internal adalah faktor yang ada dalam diri siswa berupa semangat belajar dan kreativitas yang dimiliki siswa (Riastuti \& Febrianti, 2021). Faktor eksternal adalah faktor yang ada di luar diri siswa. Kombinasi faktor ini membentuk pandangan siswa terhadap lingkungan, kemudian mempengaruhi aktivitasnya di lingkungan rumah, sekolah, dan masyarakat.

Siswa SMA menggunakan lima dari tujuh hari dalam seminggu untuk bersekolah, sehingga lingkungan sekolah memiliki kuantitas terbesar dalam mempengaruhi perilakunya terhadap lingkungan. Sekolah yang memberikan fasilitas berupa sarana prasarana, aturan, dan wawasan mengenai lingkungan hidup kepada siswa termasuk sekolah yang membentuk etika lingkungan hidup dan mendukung program ESD. Salah satu bentuk fasilitas yang disediakan sekolah adalah tempat sampah. SMAN 2 Jember memilah sampah dengan cara menyediakan tiga tempat sampah untuk tiga jenis sampah, yaitu sampah basah, sampah kering, dan sampah plastik seperti pada Gambar 1.
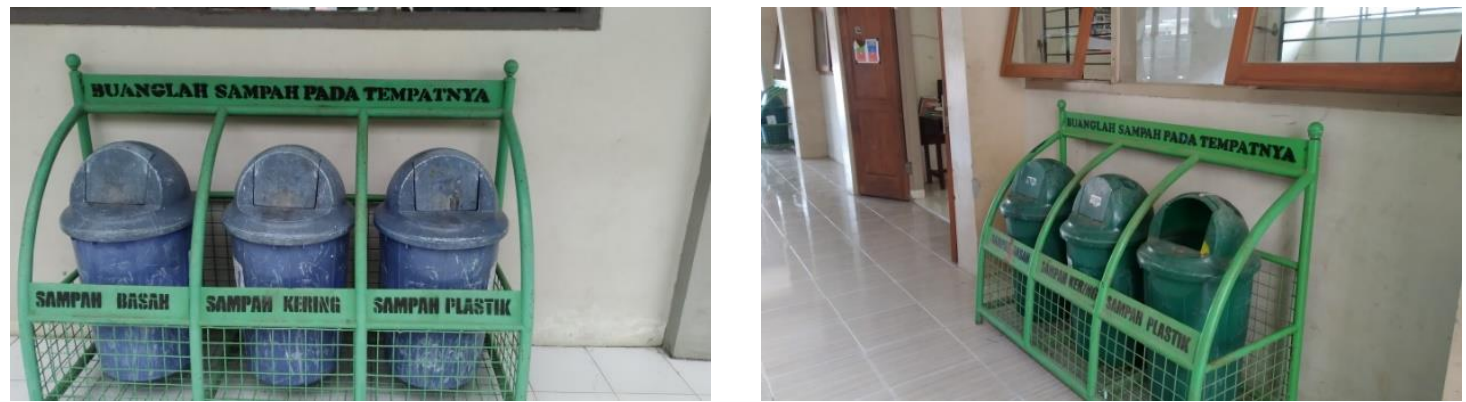

Gambar 1. Pemilihan Sampah di SMAN 2 Jember 
SMAN 5 Jember juga menerapkan pemilahan sampah. Tempat sampah di SMAN 5 Jember dibagi menjadi lima jenis, yaitu sampah non-organik, sampak organik, sampah B3, sampah kertas, dan sampah residu seperti pada gambar 4 .

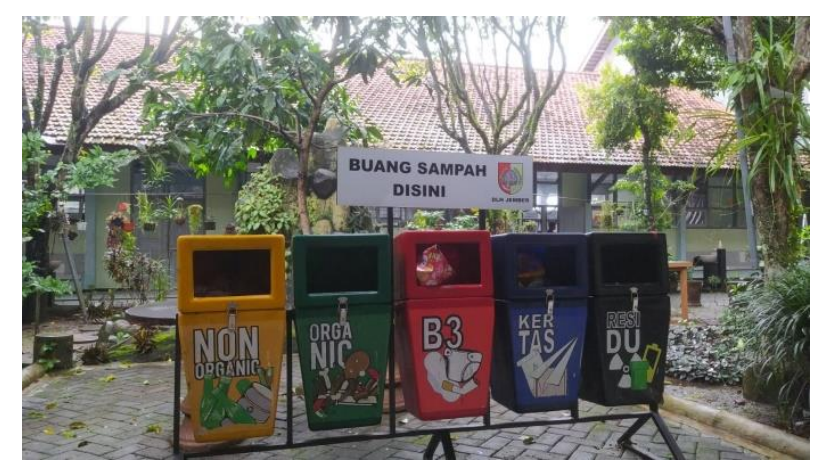

Gambar 2. Pemilahan Sampah di SMAN 5 Jember

Pemilahan sampah harus diiringi dengan sosialisasi mengenai definisi jenis - jenis sampah, apabila tidak ada sosialisasi mengenai jenis - jenis sampah, maka pemilahan tersebut tidak memberikan dampak optimal terhadap lingkungan. Terlihat jenis sampah B3 dan residu pada gambar 3. Sampah B3 (Bahan Berbahaya dan Beracun) adalah zat, energi dan/atau komponen lain yang karena sifat, konsentrasi dan/atau jumlahnya, baik secara langsung maupun tidak langsung, dapat mencemarkan dan/atau merusak lingkungan hidup, dan atau membahayakan lingkungan hidup, kesehatan, serta kelangsungan hidup manusia dan mahluk hidup lain (Peraturan Pemerintah Republik Indonesia Nomor 27 Tahun 2020, n.d.). Siswa perlu diberikan contoh seperti pada tabel 3 dari setiap jenis sampah tersebut.

Tabel 3. Contoh Sampah

\begin{tabular}{|c|c|c|c|}
\hline \multicolumn{2}{|c|}{ Sampah Organik } & \multirow{2}{*}{ Sampah Non-organik } & \multirow{2}{*}{ Sampah Residu } \\
\hline Basah & Kering & & \\
\hline Sisa makanan & Dedaunan kering & Sedotan & Baterai \\
\hline Kulit buah & Ranting kering & Kantong plastik & Lampu \\
\hline Potongan sayur & & & Tisu Basah \\
\hline
\end{tabular}

Pemilahan sampah termasuk dalam prinsip hidup sederhana dan selaras dengan alam. Setiap prinsip memiliki indikator berupa pernyataan, salah satu pernyataan pada prinsip hidup sederhana dan selaras dengan alam adalah membuang sampah sisa makanan, sampah dapur, dan kemasan plastik di tempat sampah yang sama. Pernyataan tersebut merupakan salah satu contoh perilaku prinsip hidup sederhana dan selaras dengan alam di lingkungan rumah, hal ini menunjukan pemilahan sampah tidak hanya dilakukan di lingkungan sekolah saja. Pernyataan tersebut memiliki skor 380 dari 705, maka presentasinya adalah 54\%, secara tidak langsung, hal ini menjadi penyebab nilai rata - rata perilaku etika lingkungan siswa berada dalam kategori sedang.

Penggunaan persamaan (5) untuk mencari rentang persentase menghasilkan nilai 4 (pembulatan dari 4,12). Pengelompokannya dapat dilihat pada tabel 4.

Sikap hormat terhadap alam mengindikatorkan perilaku siswa dalam menanggapi alam di sekitarnya. Prinsip ini berkaitan dengan peran siswa di lingkungan rumah, sekolah, dan masyarakat. Salah satu contohnya peran siswa di lingkungan masyarakat saat kerja bakti dan perilakunya saat hewan - hewan memasuki lingkungan rumah ataupun sekolah. Rendahnya partisipasi siswa dalam lingkungan masyarakat tampak dalam hasil kuisioner pernyataan "Saya memiliki peran saat lingkungan RT/RW mengadakan kerja bakti” memiliki skor 390 dari 705, sehingga persentasenya 55\%. Salah satu faktor yang menyebabkan rendahnya partisipasi siswa adalah pandemic COVID-19.

Solidaritas kosmis menggambarkan perilaku - perilaku kecil siswa yang mendukung kelestarian lingkungan. Penggunaan shopping bag untuk meminimalisir penggunaan plastik dan penggunaan kembali plastik - plastik dalam bentuk botol maupun kantong merupakan contoh perilaku kecil yang mewakili prinsip solidaritas kosmis. Menerapkan perilaku penggunaan kembali plastik, akan meminimalisir sampah plastik yang berpotensi menjadi mikroplastik. Mikroplastik yang ditemukan di laut, akan dikonsumsi oleh satwa laut. Penelitian membuktikan adanya akumulasi mikroplastik pada organ insang, saluran pencernaan, dan daging ikan 
(Sawalman et al., 2021). Saat prinsip solidaritas kosmis dilanggar, maka prinsip sikap hormat terhadap alam juga terlanggar. Membuang plastik yang lama terdegradasi di habitat binatang, mununjukan sikap manusia yang semena - mena. Masyarakat dapat bekerja sama dalam organisasi untuk mewujudkan masyarakat yang saling peduli terhadap pelestarian lingkungan (Wulansari et al., 2019). Begitu pula dengan siswa, siswa dapat bekerjasama dengan siswa lain untuk saling mengingatkan perilaku - perilaku yang sesuai dengan prinsip solidaritas kosmis.

Tabel 4. Kategori Persentase Prinsip

\begin{tabular}{|c|c|c|}
\hline Kategori & Rentang Presentase & Prinsip \\
\hline \multirow{6}{*}{ I } & \multirow{6}{*}{$100 \%-76 \%$} & Sikap tanggung jawab \\
\hline & & Kasih sayang dan kepedulian pada alam \\
\hline & & Hidup sederhana dan selaras dengan alam \\
\hline & & Keadilan \\
\hline & & Demokrasi \\
\hline & & Integritas moral \\
\hline \multirow{3}{*}{ II } & \multirow{3}{*}{$75 \%-51 \%$} & Sikap hormat terhadap alam \\
\hline & & Solidaritas kosmis \\
\hline & & Tidak merugikan \\
\hline III & $50 \%-26 \%$ & none \\
\hline IV & $25 \%-0 \%$ & none \\
\hline
\end{tabular}

Prinsip tidak merugikan menggambarkan perilaku manusia yang tidak memiliki dampak merugikan lingkungan. Global warming adalah dampak nyata dimana manusia merugikan lingkungan dalam memenuhi kebutuhannya, namun pada akhirnya manusia sendiri lah yang merugi. Prinsip ini mengingatkan manusia, bahwa jika manusia mengambil keputusan yang merugikan lingkungan, sesungguhnya manusia sendiri lah yang akan dirugikan kemudian hari. Perilaku sederhana yang tidak akan merugikan lingkungan adalah perilaku yang mengurangi dan hampir tidak meninggalkan jejak karbon. Jejak karbon yang paling terlihat berasal dari kendaraan. Salah satu pernyataan pada indikator prinsip tidak merugikan adalah memilih menggunakan kendaraan pribadi dibandingkan kendaraan umum. Skor yang didapatkan untuk pernyataan ini adalah 303 dari 705 atau 43\%. Siswa memerlukan edukasi mengenai aktivitas sehari - hari yang meninggalkan jejak karbon. Lingkungan rumah, sekolah, dan masyarakat menjadi bukti adanya jejak karbon. Upaya untuk mengatasi kekurangan dalam pendidikan lingkungan hidup yakni sekolah seharusnya memberikan pengajaran praktik yang efisien dan efektif dalam rangka meningkatkan prilaku peduli terhadap lingkungan dan juga lingkungan belajar seharusnya mengajak siswa belajar di alam terbuka untuk mengamati, mempraktekkan dan menguji problem permasalahan lingkunan (Ismail, 2020). Mengurangi penggunaan kendaraan pribadi dan mengkonsumsi sayuran pengganti daging adalah perilaku sehari - hari yang dapat menurukan jejak karbon.

Prinsip kasih sayang dan kepedulian terhadap alam telah ditunjukan oleh siswa melalui perilaku memilah sampah di lingkungan sekolah, menghormati peraturan lingkungan saat di tempat wisata, dan tidak membiarkan sampah berserakan di kelasnya. Perilaku ini terwujud dalam skor pernyataan tidak membuang sampah di daerah pantai mencapai 684 dari 705, hal ini menunjukan 97\% siswa tidak membuang sampah di daerah pantai. Prinsip hidup sederhana dan selaras dengan alam dapat terwujud saat siswa mendapatkan pembelajaran yang berwawasan lingkungan. Pembelajaran berwawasan lingkungan membuat Siswa menjadi lebih tau, paham dan sadar pentingnya karakter yang baik dan menjaga lingkungan agar tempat yang ia singgahi nyaman untuk beraktifitas (Ratih et al., 2020). Sekolah Adiwiyata merupakan salah satu program yang mendukung prinsip tersebut. SMAN 5 Jember merupakan salah satu sekolah yang menerima penghargaan Adiwiyata Tingkat Nasional pada tahun 2009 dan 2010. SMAN 5 Jember mendapatkan predikat Sekolah Adiwiyata Mandiri oleh Susilo Bambang Yudhoyono (Presiden Republik Indonesia ke - 6).

Siswa telah memiliki perilaku yang selaras dengan prinsip demokrasi, integritas moral, keadilan, dan sikap tanggung jawab terhadap lingkungan. Siswa SMA memiliki kemampuan locus of control (pengendalian diri) yang lebih tinggi dibanding sebelumnya. Locus of Control akan mempengaruhi cara pandang siswa tentang Sustainable Society. Mengembangkan dan memperkuat locus of control secara internal adalah fokus dasar dari pendidikan di sekolah (Hidayat et al., 2020). Locus of control internal adalah kunci bagi siswa untuk memperkirakan perilaku perilaku saat ini sebagai aksi dari faktor - faktor di lingkungan (Fukuzawa \& Inamasu, 2020). Pandangannya 
terhadap lingkungan, mampu memutuskan perilaku yang mereka lakukan. Siswa menyadari bahwa kepentingan bersama lebih diutamakan dari kepentingan pribadi. Siswa mulai menyadari tanggung jawab yang dimiliki untuk lingkungan sekitarnya pada masa kini dan mendatang.

\section{SIMPULAN}

Hasil penelitian menunjukan nilai rata - rata perilaku etika lingkungan siswa SMAN di Jember adalah 74,38 dan tergolong dalam kategori sedang. Tiga prinsip dalam kategori II ( $75 \%-51 \%$ ) yaitu, prinsip sikap hormat terhadap alam, solidaritas kosmis, dan tidak merugikan. Prinsip sikap tanggung jawab, kasih saying dan kepedulian terhadap alam, hidup sederhana dan selaras dengan alam, keadilan, demokrasi, integritas moral termasuk dalam kategori I (100\% - 76\%). Prinsip tidak merugikan memiliki presentase terendah, yaitu sebesar $52 \%$, sedangkan prinsip demokrasi memiliki presentase tertinggi, yaitu sebesar $98 \%$.

\section{Ucapan Terima Kasih}

Penulis mengucapkan terimakasih kepada lembaga - lembaga yang telah bersedia mendukung penelitian ini, yaitu SMA Negeri 2 Jember, SMA Negeri 4 Jember, dan SMA Negeri 5 Jember.

\section{Daftar Pustaka}

Akbar, A., \& Ali, A. M. (2021). Peran Sekolah dalam Upaya Pelestarian Greend Child Sebagai Upaya Pelestarian Lingkungan Hidup. Sang Pencerah: Jurnal Ilmiah Universitas Muhammadiyah Buton, 7(3), 321-327. https://doi.org/10.35326/pencerah.v7i3.1181

Andrasmoro, D., Nurhakim, I., Mustofa, M., \& Bayuardi, G. (2020). KUALITAS PEMBELAJARAN ETIKA LINGKUNGAN BAGI SISWA SEKOLAH SMA NEGERI 3 SUNGAI KAKAP. 5(1), 20-25. https://doi.org/10.26737/jpipsi.v5i1.1516

Arikunto, S. (2013). Dasar Dasar Evaluasi Pendidikan Edisi Kedua. Bumi Aksara. https://www.google.co.id/books/edition/Dasar_Dasar_Evaluasi_Pendidikan_Edisi_3/j5EmEAAAQBA $\mathrm{J} ? \mathrm{hl}=\mathrm{id} \& \mathrm{gbpv}=0$

Faizah, U. (2020). Etika Lingkungan dan Aplikasinya dalam Pendidikan Menurut Perspektif Aksiologi. Filsafat Indonesia, 3(1), 14-22. https://doi.org/http://dx.doi.org/10.23887/jfi.v3i1.22446

Fukuzawa, A., \& Inamasu, K. (2020). Relationship between the internal locus of control and collective action: A comparison of East Asian and Western Countries. Asian Journal of Social Psychology, 23(3), 349-359. https://doi.org/10.1111/AJSP.12406

Hayashi, K. (2020). Stationarity of spot freight rates considering supply/demand effect. Journal of Shipping and Trade, 5(1). https://doi.org/10.1186/s41072-020-00078-8

Hidayat, H., Tamin, B. Y., Herawati, S., Ardi, Z., \& Muji, A. P. (2020). The Contribution of Internal Locus of Control and Self-Concept to Career Maturity in Engineering Education. International Journal on Advanced Science, Engineering and Information Technology, 10(6), 2282-2289. https://doi.org/10.18517/ijaseit.10.6.11698

Hudha, A. M., \& Husamah, H. (2019). Ethics of Domestic Tourist to Beach Conservation (Case Study of Balekambang Beach, Malang District). Jurnal Pengelolaan Sumberdaya Alam Dan Lingkungan (Journal of Natural Resources and Environmental Management), 9(1), 9-16. https://doi.org/10.29244/jps1.9.1.9-16

Ismail, A. (2020). Potensi Penurunan Emisi Gas Rumah Kaca (Grk) Dalam Kegiatan Belajar Di Rumah Secara on-Line: Analisis Jejak Karbon (Carbon Footprint Analysis). Jukung (Jurnal Teknik Lingkungan), 6(2), 195203. https://doi.org/10.20527/jukung.v6i2.9262

Keraf, A. S. (2010). Etika lingkungan hidup. Penerbit Buku Kompas.

Martino, L., Luengo, D., \& Míguez, J. (2018). Independent Random Sampling Methods. https://doi.org/10.1007/978-3-319-72634-2

Næss, A., Drengson Alan, \& Devall Bill. (2016). Ecology of wisdom. Penguin Books. 
Nissa, K., \& Christiawan, P. I. (2018). Etika Lingkungan Masyarakat Pesisir Di Kota Singaraja. Jurnal Pendidikan Geografi Undiksha, 6(3), 154-162. https://doi.org/10.23887/jjpg.v6i3.20702

Nita, S., \& Kartikawati, S. (2020). Analysis of the Impact Narrative Algorithm Method, Pseudocode and Flowchart Towards Students Understanding of the Programming Algorithm Courses. IOP Conference Series: Materials Science and Engineering, 835(1). https://doi.org/10.1088/1757-899X/835/1/012044

PERATURAN PEMERINTAH REPUBLIK INDONESIA NOMOR 27 TAHUN 2O2O. (n.d.).

Ratih, K., Utami, R. D., Fuadi, D., Mulyasih, S., Febriani, D., Asmara, S. F., Aprilianti, D. R., Rianti, A. W., Santiana, D., Rahmawati, H., Adlina, L. M., Rosyidi, B., \& Hidayat, M. T. (2020). Penguatan Pendidikan Etika dan Karakter Peduli Lingkungan Sosial Budaya di SMP Muhammadiyah 10 Matesih, Karanganyar. Buletin KKN Pendidikan, 2(1), 44-49. https://doi.org/10.23917/bkkndik.v2i1.10770

Riastuti, R. D., \& Febrianti, Y. (2021). STUDI DOKUMENTER HASIL BELAJAR PSIKOMOTORIK SISWA SMA PADA MATERI SISTEM PERNAPASAN MELALUI MODEL PEMBELAJARAN PROJECT BASED LEARNING (PjBL). 4(1), 6. https://doi.org/https://doi.org/10.31539/bioedusains.v4i1.2206

Said, M. Y., \& Nurhayati, Y. (2020). PARADIGMA FILSAFAT ETIKA LINGKUNGAN DALAM MENENTUKAN ARAH POLITIK HUKUM LINGKUNGAN. XII(1), 1-23. https://doi.org/http://dx.doi.org/10.31602/al-adl.v12i1.2598

Sawalman, R., Zamani, N. P., Werorilangi, S., \& Samira, I. M. (2021). AKUMULASI MIKROPLASTIK PADA SPESIES IKAN EKONOMIS PENTING DI PERAIRAN PULAU BARRANGLOMPO, MAKASSAR. Jurnal Ilmu Dan Teknologi Kelautan Tropis, 13(2), 241-259. https://doi.org/https://doi.org/10.29244/jitkt.v13i2.34587

Sudaryono, S. (2021). Statistik I: Statistik Deskriptif untuk Penelitian. Penerbit Andi. https://doi.org/6230116421

Wulansari, F. A., Komariah, S., \& Waluya, B. (2019). Pembinaan Solidaritas Masyarakat Melalui Lamongan Green and Clean di Desa Pucangro Kecamatan Kalitengah, Kabupaten Lamongan. Indonesian Journal of Sociology, Education, and Development, 1(2), 82-95. https://doi.org/10.52483/ijsed.v1i2.8 